At first the Parsons turbine was used without a condenser and was " a notorious steam eater". How Parsons brought in the compound turbine, the condensing turbine, the marine turbine, and the geared turbine, and how he successfully attacked the many problems which arose as the turbine gradually superseded steam engines in powerhouses and ships, Sir Alfred made clear with the help of lantern slides, but unfortunately the report of his lecture has no illustrations.

It was once said that the work of Parsons had halved the cost of generating electricity. That is probably well within the mark. The relative importance of turbine plant to-day is shown by the official statistics quoted by Sir Alfred, "British power-stations in 1930 ", he said, " show that steam turbines provided more than $5 \frac{1}{2}$ million kilowatts, while all the other types of heat engines accounted for less than a quarter of a million." But neither the generation of power nor the propulsion of ships monopolised the activities of Parsons. He spent much time and money in the attempt to produce artificial diamonds, worked out a scheme for boring a shaft in the earth's crust 12 miles deep, studied the casting of large steel ingots, and in his later years turned to the subjects which had engrossed his father and became a maker of optical glass and a constructor of large telescopes. No one to-day doubts that he was the most illustrious engineer of his time, and a biography of him should prove of the greatest value to students of both science and engineering.

\title{
The Great Barrier and the Formation of Coral Reefs
}

$\mathrm{D}^{\mathrm{H}}$ R. YONGE divided the plan of operations of the Great Barrier Reef Expedition into four sections : (1) the detailed study of the feeding of corals; (2) the plankton and sea-water; (3) an ecological study of corals and associated organisms ; and (4) the examination of the bottom flora and fauna, with the determination of the zoning of life at increasing depths (NATURE, 121, 213; 1928). The British Museum (Natural History) has now commenced to publish the results in these four sections. Dr. Yonge's own work is mainly included in vol. 1 and has been already sufficiently summarised in Nature, $12 \%, 309 ; 1931$. It is a very remarkable study of the feeding of corals, from which he concludes that symbiotic algæ are " an indispensable factor in the necessarily exceptional powers of growth and repair possessed by the marine communities known as coral reefs". This is as much as concerns the student of the formation of coral reefs.

The methods for the collecting of zooplankton, designed mainly by F. S. Russell, require careful study, but comment is deferred until some quantitative and qualitative results are published. There were 189 hauls of the nets at 68 stations, together with a series of reef-flat plankton collections. For comparative purposes it would be useful if future marine expeditions adopted similar methods. The number of new species of animals obtained in the plankton may be small, the geographical region being the tropics, but the wealth of the collections is indicated in Mr. Barnard's "Amphipoda ", more than a thousand specimens (23 species) of Hyperiidea having been submitted to him for examination.

Vol. 3 contains papers relating to the structure and ecology of reefs. J. A. Steers's geographical introduction is intended for biologists who deal "with definite facts" while geographers "deal with theory". He might have added that biologists on this expedition set out to obtain and test their facts largely by experiment, thus differentiating this from all previous expeditions. Mr. Steers's main work is published in the Geographical Journal, wherein he considers the formation of the Great Barrier Reef. He accepts the view that there was a post-glacial rise of sea-level, the coast platform having been formed largely by low-level Pleistocene abrasion, this following on downfaulting of a peneplain, composed of Pre-Tertiary rocks.

Dr. Stephenson contributes a happy report containing the outlines of the "Development and the Formation of Colonies in Pocillopora and Porites". He also, assisted by some members of his party, writ es a long account of Low Isles and other lagoon reefs, and of one piece of the Barrier Reef. A ccording to Miss Marshall and Dr. Orr's borings, Low Isles reef is a mere veneer of corals and other organisms covering a mud bank (NATURE, $129,141 ; 1932)$. It has a very different foundation from any coral reef visualised by Darwin or any other student of the formation of coral reefs. Dr. Stephenson states that the organisms are extending the surface of the reef outwards, presumably debris being laid down in the waters around in such a way that this outgrowth is assisted. The reef itself was formed as one or more reef patches of a type described as "made of dead boulders and masses of coral with sand between and the surface . . . very irregular and full of complex holes and crevices". The slope to the barrier lagoon is " covered by fixed blocks of dead coral of varying shape" and is illustrated by useful sections. "As the depths of the water increases they tend to become higher, and many of them form very large mounds", the tops often exposed at low water. Their sides are $20 \mathrm{ft}$. or more deep, and corals grow "on top of them and a little below the top". Nearer the shore they give place to a rugged area "covered by fixed blocks of dead coral". These perpendicular mounds seem to resemble those in the "zone of coral heads" on the lagoon side of Yonge Reef in the barrier series and formerly described in similar places by Surgeon Paradice, who is not referred to. Where I have seen similar structures they were in decay or stationary, and I await further evidence that they have been built

No. 3264, VoL. 129] 
up by corals and are being added to the reef; in particular, I would learn of the destructive as well as of the constructive organisms and processes in and around Low Isles reef.

Dr. Stephenson should give his reference where he objects to the words "a typical coral reef" as "improper". Surely it is as improper to apply the names he has invented for parts of Low Isles Reef to Yonge Reef of the outer barrier, which appears to have been largely mortared and built by calcareous algæ not present in the former. Yonge Reef has no land and, except boulders, no part projecting above ordinary low tide level, whereas these inner reefs of the lagoon have an elaborate arrangement of cays, ramparts, and rocks above the level at which the building corals can live. Does our author reject the idea that there has been a lowering of sea-level in these regions in very recent times? There is " a general consensus of opinion amongst those who know" as to this (Steers), but in the summary of this report it is not even referred to. Were the superficial structures of Low Isles examined with this recent negative displacement of sea-level in view ? If not, they require re-examination. In particular, the rocks shown in Plate V., Figs. 3 and 4, might just as well be parts of a formerly continuous reef which is slowly washing away as boulders; if so, many of their building organisms should be in the position in which they grew.

Yonge Reef "was chosen for careful examination" so that a full account will doubtless follow. It is of infinitely greater importance to the student of coral reef questions than all these lagoon reefs. A reef against the open ocean in such a position has usually an outer narrow ridge a few yards behind the breakers broken by trenches, a reef flat at about low tide level, often in places a little lower, a boulder zone, and a lagoon flat. Yonge Reef is described as having the same outer ridge, inside which is a depression (outer moat) up to $5 \mathrm{ft}$. deep and 100 yards broad. Then comes the " reef crest . . . a pavement of solid coral rock, swept clear of debris . . 160 yards in breadth", more or less exposed at low water, and this is succeeded by an ill-defined depression (inner moat) 50 yards broad, up to $18 \mathrm{in}$. deep, rising into the boulder zone. The crest and inner moat seem to us to be comparable with the inner half of what is termed the reef-flat and to carry the same organisms, but the outer depression, up to $5 \mathrm{ft}$. deep, is a most unusual feature that merits full description. We presume that it was found at Ribbon, Ruby, and Escape Reefs, justifying the statement that Yonge Reef is typical. It would help us to understand this reef had there been any mention of the genera of building algæ in the list of its fauna and flora and referred to as a "heavy incrustation of nullipores". In any event, Yonge Reef should never have been blended in this report with a series of lagoon reefs many miles away from the open ocean, for it will throw those who have not made personal examinations of coral reefs into inextricable confusion.

The systematic work of the bottom fauna is published in vol. 4, which at present contains nine reports. It commences with that of the Annelida by Mr. C. C. A. Monro, but was it worth his time to examine a collection of 46 species of Chrtopoda, of which more than half are represented only by single specimens? Clearly this class of animal, so important on shallow reefs, was never collected, and subsequent reports lead us to believe that only the obvious forms of life in such positions were collected. Enteropneusts suggest a similar story, only 2 species with 12 species of larvæ being described by $\mathrm{E}$. Trewavas. Low island reefs should be almost ideal for the adults, and yet there are recorded only 21 specimens of Ptychodera flava and 8 "fragments" of Balanoglossus carnosus, which is described as " common on most sandy places". If only Mr. Monro, who has the specialist's knowledge, could be sent out to collect such groups of animals, on a tropical coral reef coast, what information we would have! He would settle his species on the spot, and in a second year his report would be completed! It would be of more value to science than twenty years in a museum working on collections such as this. Neither he nor Mr. Lyman Clark, who had more than five hundred specimens of Echinoderma other than Asteroidea, 117 species in 66 genera, thinks it worth while to consider geographical distribution. There are very few field notes, and the reader will inevitably conclude that the expedition did little collecting work. This is unfortunate, as a knowledge of the whole fauna and flora of the region is essential to an ecological study of any part.

Another report in this series is Prof. S. J. Hickson's revision of the genera and species of the Xeniidæ. It is of high scientific importance and of great educational value to future taxonomic workers on sedentary animals. The desirability of field observations is clear, Dr. Manton's note, " not the same species as on Escape Reef ", leading to the discovery of a new species. It is also pleasing to see that the British Museum has a good taxonomist to deal with Tunicates in the person of A. B. Hastings, who appears temporarily to have deserted Polyzoa. G. P. Whitley, ichthyologist to the Australian Museum, collected most of the three hundred and fifty specimens of fish, which he assigned to a hundred species, and his field notes are fuller than usual. He remarks that the region is not sufficiently analysed for a synthesis of the geographical distribution of fish. A. A. Livingstone, of the same museum, has 33 species in 20 genera of Asteroidea, but by a slip New Ireland is placed in the Maldives. We would also refer to an excellent study of Trochus by the Australian naturalist, F. W. Moorhouse (vol. 3). It feeds on algæ, which it rasps off the rocks, and its optimal area appears to be on the relatively bare weather sides of reefs between tide marks, where the water is well aerated and every bare surface is covered by such algæ. Tables of size frequencies and of monthly rates of growth are given. Breeding takes place after two years, the Trochus being then about $5.5 \mathrm{~cm}$. in diameter, the full size being about $9 \mathrm{~cm}$. J. Stanley Gardiner. 